\title{
THE POTENTIAL ROLE OF SERUM S100B PROTEIN AS A PREDICTOR OF ACUTE TRAMADOL OVERDOSE INDUCED SEIZURE
}

\author{
Ghada N. El-Sarnagawy and Doaa M. El-Gharbawy \\ Forensic Medicine and Clinical Toxicology Department, Faculty of Medicine, Tanta \\ University, Tanta, Egypt
}

\begin{abstract}
Background: Tramadol poisoning is one of the major health problems worldwide especially in developing countries. Seizure is considered a serious and life-threatening manifestation of acute tramadol overdose. Recently, serum S100B protein has been shown to be a useful and specific neuro-biochemical marker of central nervous system damage. Aim of the study: To assess the role of serum S100B protein on admission as a predictor of seizure occurrence in patients with acute tramadol poisoning and to determine the factors affecting tramadol-induced seizure. Participants and methods: Thirty-three patients with acute tramadol poisoning, of both sexes, and 20 healthy sexand age-matched volunteers as a control group were included in this study. The studied tramadol poisoned patients were classified into two groups; group I: Seizure group and group II: Non-seizure group. For all patients, demographic and poisoning data were recorded then clinical evaluation and investigations were performed. Serum S100B level was estimated on admission. Results: : There was a statistically significant difference between patients with seizures and patients without seizures regarding age group, gender, ingested tramadol dose, Glasgow coma scale (GCS), poisoning severity score (PSS) and administered naloxone dose. On the other hand, there was no significant difference between both groups in manner of poisoning, delay time, vital data, oxygen saturation, arterial blood gases $\& \mathrm{pH}$ and hospitalization period. The mean serum S100B was significantly higher in tramadol poisoned patients when compared to the control group; moreover, it was significantly elevated in patients with seizures than patients without seizures. Serum S100B as a predictor of seizures showed AUC $=0.863(\mathrm{p}=<0.001)$ at cut-off value $>0.58 \mu \mathrm{g} / \mathrm{L}$ with $75 \%$ sensitivity and $95.24 \%$ specificity. Conclusion: Serum S100B could be used as a good predictor of tramadol-induced seizure and it could be useful to assess clinical severity in acute tramadol overdose. Moreover, young adult males, increased ingested tramadol dose, increased administered naloxone dose and decreased level of consciousness are considered risk factors of tramadol-induced seizures.
\end{abstract}

Keywords: Tramadol, seizures, poisoning, S100B, biomarker, predictor.

\section{INTRODUCTION}

Currently, opioids uses and their related morbidity and mortality are being one of the major health problems worldwide (Eizadi-Mood et al., 2014). Tramadol is atypical, synthetic and centrally-acting analgesic that is related to codeine and morphine in structure
(Duke et al., 2011 and Nasouhi et al., 2015).

Tramadol was ranked as a second cause of acute poisoning after oxycodone in annual reports of the American Association of Poison Control Centers Toxic Exposure Surveillance (Watson et al., 2003). Furthermore, a study in Tehran, Iran 
reported that tramadol-related deaths in 2008 were 32.5 times more than in 2005 (Iravani et al., 2010). In Egypt, the incidence of tramadol poisoning was increased in the last years. The Poison Control Center (PCC) of AinShams University Hospitals, Cairo, Egypt recorded 1595 patients with acute tramadol poisoning in the period between October 2010 and September 2011 (El-Masry \& Tawfik, 2013 and Fouad et al., 2015).

Tramadol produces its analgesic effects by dual mechanisms; opioid and non- opioid mechanisms (Afshari \& Ghooshkanehee, 2009). It has low affinity to $\mu$-opioid receptors. Therefore, most of its analgesic effect is due to its non-opioid properties via reuptake inhibition of central monoamines especially serotonin and norepinephrine (Taghaddosinejad et al., 2011 and Majidi \& NekoueiFard, 2014).

Acute tramadol poisoning manifestations include nausea, vomiting, constipation, lethargy, coma and respiratory depression. Tramadol overdose might also present with features of the serotonin syndrome due to serotonin-norepinephrine reuptake inhibition rather than its opioid effects; which may include neuromuscular hyperactivity (myoclonus and hyperreflexia), autonomic hyperactivity (tachycardia, hypertension and pyrexia) and altered mental state (agitation, excitement and later confusion)

(Pothiawala \& Ponampalam, 2011; Boostani \& Derakhshan, 2012 and Rahimi et al., 2014).

Seizure was reported in $15-35 \%$ of tramadol intoxicated cases; meanwhile, it could also occur in therapeutic doses. There are different mechanisms that could explain tramadol-induced seizure as gamma-aminobutyric acid inhibitory pathways or histamine $(\mathrm{H} 1)$ receptor involvement or reuptake inhibition of norepinephrine and serotonin. Although tramadol poisoning may be non-life-threatening but, if accompanied by seizures it has been associated with reports of increased morbidity and mortality (Farzaneh et al., 2012 and Eizadi-Mood et al., 2014)

Recently, some neuro-biomarkers as S100B, neurospecific enolase, Tau protein and glial fibrillary acidic protein have been investigated as diagnostic and prognostic markers of central nervous damage in acute poisoning (Akdemir et al., 2014 and Sykes \& Walker, 2016). S100B is a calcium binding protein found primarily in astroglial cells and Schwann cells. It plays an important role in neurodevelopment, differentiation and brain construction. It increases following brain damage, which easily penetrates into cerebrospinal fluid then into the blood. A normal S100B level has constantly been applied to predict the absence of major CNS damage and increased serum S100B level is not related only to neuroglia damage but could also reveal the current failure of the blood brain barrier (Liu et al., 2015 and Sykes \& Walker, 2016 ).

There is limited information about factors affecting tramadol-induced seizure and no available data evaluating the role of serum S100B in acute tramadol poisoning. Therefore, this study aimed to assess the role of serum $\mathrm{S} 100 \mathrm{~B}$ protein, on admission, as a predictor of seizure in patients with acute tramadol poisoning and to determine the factors affecting tramadol-induced seizures. 


\section{PARTICIPANTS \& METHODS}

Study design and ethical points:

This prospective study was conducted on thirty-three patients, of both sexes, with acute tramadol poisoning who were admitted to Tanta Toxicological Unit during the period from July 2014 to June 2015 and 20 healthy sex- and age-matched volunteers as a control group. The study was approved by Research Ethics committee of Tanta Faculty of Medicine. Written informed consents were obtained from adult conscious participants or guardians of teenagers after complete description of the study. All patients' data were recorded in special sheets and the privacy and confidentiality of these data and records were ascertained through coding system.

\section{Patients:}

All patients aged 18 years or more, of both sexes, with acute tramadol poisoning admitted within 24 hours, during the study period, were included. Exclusion criteria included: patients with previous or family history of epilepsy, traumatic head injuries, neuropsychiatric disorders and patients with history of other poisonings or drug co-ingestion as well as patients with positive urine screen test for substance abuse including; benzodiazepines, barbiturates, opiates, methadone, amphetamine and tricyclic antidepressants. Furthermore, transferred patients from other hospitals, patients with systemic comorbidities including metabolic, endocrinal or cardiac causes and infections were also excluded from the study.

Electrocardiography (ECG), head computed tomography (CT) scan and laboratory investigations including liver and renal function tests, complete blood count (CBC), random blood glucose level, sodium $(\mathrm{Na})$ and potassium $(\mathrm{K})$ levels were performed for every participant to exclude the patients who did not fulfill the criteria of the study.

Diagnosis of tramadol poisoning was based on history, characteristic symptoms \& signs and, urinary screening analysis of tramadol. The studied tramadol poisoned patients were classified into two groups; Group I (Seizure group; patients having seizures) and Group II (Non-seizure group; patients do not having seizures). Diagnosis of seizure was based on jerky movements of the whole body, tonic/clonic spasms and convulsions (Eizadi-Mood et al., 2014). All volunteers of the control group gave negative history for taking any drugs and had negative urinary immunoassay for substances of abuse.

\section{Methods:}

For all patients, demographic data (age, sex, time of admission), poisoning data (name of drug, dose, route of exposure, mode of poisoning, delay time between exposure and arrival to hospital "pre-hospitalization period") and onset of seizures were recorded.

Clinical evaluation was performed for all patients including initial vital signs (blood pressure, pulse rate, respiratory rate and temperature), initial Glasgow Coma Scale (GCS), and poisoning severity score (PSS). Additionally, the administered naloxone dose, endotracheal intubation need and hospitalization period were documented. Serum S100B level, arterial blood gases (ABG) and $\mathrm{pH}$ were measured for all patients on admission and before treatment. 
Three milliliters venous blood samples for S100B estimation were collected immediately on admission in plain test tubes. The whole blood was allowed to clot at room temperature for 30 min. Then, the samples were centrifuged at $3000 \mathrm{rpm}$ for $10 \mathrm{~min}$. Following centrifugation, the serum was separated and deeply stored at -80 ${ }^{\circ} \mathrm{C}$ until analysis for maximum of 6 months.

Quantification of human serum S100B protein was performed in accordance with the direction of manufacture by double antibody sandwich enzyme linked immunosorbent assay (ELISA) using Human S100B ELISA kit (Shanghi Sunred Biological Technology Co., Ltd, Shanghai, China). The results were expressed as $\mu \mathrm{g} / \mathrm{L}$. Also, one-milliliter arterial blood sample was taken on heparinized tube for estimation of arterial blood gases and $\mathrm{pH}$.

Moreover, $20 \mathrm{ml}$ of urine samples were collected from each patient on admission in clean dry sterile disposable containers, labelled with patient's name, serial number and date of taking the sample then were preserved at $-20^{\circ} \mathrm{C}$.

Urine screening analysis was done for detection of tramadol and to exclude any other drugs or substances of abuse such as benzodiazepines, opiates, barbiturates, cocaine, cannabinoids and amphetamines by using (Quick Profile ${ }^{\mathrm{TM}}$ DOA/Alcohol Panel Test Device; Lumi Quick Diagnostic Inc., Santa Clora, CA, USA); which is an immunoassay based one step drug of abuse rapid in-vitro test in human urine.

\section{Statistical analysis}

The collected data were organized and statistically analyzed using SPSS software computer package for windows version 22 (SPSS Inc., Chicago, Illinois, USA). For quantitative data, the Shapiro-Wilk test for normality was performed. For data that were not normally distributed median and interquartile range (expressed as $25^{\text {th }}-75^{\text {th }}$ percentiles) were calculated and Mann-Whitney test was used for comparison between groups and Spearman's correlation was performed. For normally distributed data, values were expressed as mean \pm standard deviation and independent sample student t- test was used for comparison. One sample t- test was used to compare S100B in the studied patients to the control group. For qualitative data, Pearson's Chi-square or Fisher's Exact tests were used as appropriate (Dawson-Saunders \& Trapp, 2001). The receiver operating characteristic (ROC) curve was used to calculate cut-off value, sensitivity and specificity of S100B level according to Delong et al. (1988). Significance was adopted at $p<0.05$ for interpretation of results of tests.

\section{RESULTS}

Thirty-three patients with acute tramadol poisoning were included in this study. The ages of the studied patients ranged from 18 to 46 years with a mean age $25.6 \pm 9.3$ years and most of the studied patients were young adult males aged between 21 to 40 years (63.6\%). Toxicological data revealed that, the route of exposure was oral in all cases. The majority of cases $(63.6 \%)$ were intoxicated due to suicidal attempts followed by tramadol abusers $(27.3 \%)$. The mean delay time was $5.3 \pm 2.1$ hours. The ingested tramadol dose in the studied patients ranged from 150 to $3000 \mathrm{mg}$ with a 
median of $800 \mathrm{mg}$. The hospitalization period ranged from 24 to 125 hours and its median was 72 hours (table 1).

There was statistically significant difference between patients with seizures and patients without seizures regarding age decades, gender and ingested tramadol dose. However, there was no significant difference between both groups regarding the manner of poisoning, delay time or hospitalization period

(table

1).

Table (1): Demographic and toxicological findings of the studied patients ( $\mathrm{n}=33)$

\begin{tabular}{|c|c|c|c|c|c|c|}
\hline Variables & & $\begin{array}{l}\text { Group I } \\
\text { Seizure } \\
\text { group } \\
(n=12)\end{array}$ & $\begin{array}{l}\text { Group II } \\
\text { Non-seizure } \\
\text { group } \\
(\mathbf{n}=\mathbf{2 1})\end{array}$ & $\begin{array}{c}\text { Total } \\
\text { studied } \\
\text { patients } \\
(n=33)\end{array}$ & $\begin{array}{c}\text { Test } \\
\text { statistic }\end{array}$ & p value \\
\hline \multirow[b]{2}{*}{ Age (years) } & Range & $25.0-31.0$ & $18.0-46.0$ & $18.0-46.0$ & \multirow[b]{2}{*}{$t=-1.484$} & \multirow[b]{2}{*}{0.151} \\
\hline & Mean \pm SD & $28.0 \pm 2.7$ & $24.1 \pm 11.4$ & $25.6 \pm 9.3$ & & \\
\hline \multirow{3}{*}{$\begin{array}{l}\text { Age decades } \\
\text { N (\%) }\end{array}$} & $\leq 20$ Years & $0(0.0 \%)$ & $9(42.9 \%)$ & $9(27.3 \%)$ & \multirow{3}{*}{$\begin{array}{l}X_{\mathrm{FE}}^{2}= \\
10.600\end{array}$} & \multirow{3}{*}{$0.003^{*}$} \\
\hline & 21-40 Years & $12(100.0 \%)$ & $9(42.9 \%)$ & $21(63.6 \%)$ & & \\
\hline & $>40-60$ Years & $0(0.0 \%)$ & $3(14.3 \%)$ & $3(9.1 \%)$ & & \\
\hline \multirow{2}{*}{$\begin{array}{c}\text { Gender } \\
\mathbf{N}(\%) \\
\end{array}$} & Male & $12(100.0 \%)$ & $9(42.9 \%)$ & $21(63.6 \%)$ & \multirow{2}{*}{$\begin{array}{l}\mathrm{X}^{2} \mathrm{Chs}= \\
8.448\end{array}$} & \multirow{2}{*}{$0.004 *$} \\
\hline & Female & $0(0.0 \%)$ & $12(57.1 \%)$ & $12(36.4 \%)$ & & \\
\hline \multirow{3}{*}{$\begin{array}{c}\text { Manner of } \\
\text { poisoning } \\
\mathbf{N}(\%)\end{array}$} & Accidental & $0(0.0 \%)$ & $3(14.3 \%)$ & $3(9.1 \%)$ & \multirow{3}{*}{$\begin{array}{c}\mathrm{X}_{\mathrm{FE}}^{2}= \\
1.738\end{array}$} & \multirow{3}{*}{0.487} \\
\hline & Suicidal & $9(75.0 \%)$ & $12(57.1 \%)$ & $21(63.6 \%)$ & & \\
\hline & Addict & $3(25.0 \%)$ & $6(28.6 \%)$ & $9(27.3 \%)$ & & \\
\hline \multirow{3}{*}{$\begin{array}{c}\text { Tramadol dose } \\
(\mathrm{mg})\end{array}$} & Range & $200-3000$ & $150-1600$ & $150-3000$ & \multirow{3}{*}{$\begin{array}{l}\mathrm{Z}_{\mathrm{MW}}= \\
2.012\end{array}$} & \multirow{3}{*}{$0.044 *$} \\
\hline & Median & 1200 & 600 & 800 & & \\
\hline & IQR & $650-2125$ & $400-900$ & $400-1200$ & & \\
\hline \multirow{2}{*}{$\begin{array}{c}\text { Delay time } \\
\text { (hours) }\end{array}$} & Range & $3.0-10.0$ & $2.5-7.0$ & $2.5-10.0$ & \multirow[b]{2}{*}{$\mathrm{t}=-2.015$} & \multirow[b]{2}{*}{0.053} \\
\hline & Mean \pm SD & $6.3 \pm 2.6$ & $4.8 \pm 1.6$ & $5.3 \pm 2.1$ & & \\
\hline \multirow{3}{*}{$\begin{array}{l}\text { Hospitalization } \\
\text { period (hours) }\end{array}$} & Range & $24.0-120.0$ & $24.0-125.0$ & $24.0-125.0$ & \multirow{3}{*}{$\begin{array}{l}Z_{\mathrm{MW}}= \\
-0.637\end{array}$} & \multirow{3}{*}{0.542} \\
\hline & Median & 72.0 & 55.50 & 72.0 & & \\
\hline & IQR & $38.0-98.0$ & $25.5-106.5$ & $30.0-98.0$ & & \\
\hline
\end{tabular}

$\mathrm{SD}=$ Standard deviation, $\mathbf{t}=$ Independent samples $\mathbf{T}$ test, $\mathbf{X}_{\mathrm{FE}}{ }^{2}=$ Fisher's Exact test, $\mathbf{X}^{2}{ }_{\text {ChS }}=$ Pearson's Chi-square test for association, $I Q R=$ Interquartile range, $\mathbf{Z}_{\mathrm{Mw}}=$ MannWhitney test, *Significance at $\mathbf{p}<0.05$.

Tables ( 2 and 3 ) demonstrated that pulse rate, temperature and blood pressure were within normal ranges in most of all studied cases $(63.6 \%$, $81.8 \%$ and $90.9 \%$ respectively), while tachycardia was recorded in $27.3 \%$ of cases. Bradypnea and respiratory acidosis occurred in $54.5 \%$ of cases per each. Also, hypoxia was recorded in $63.7 \%$ of studied patients. Seizure was recorded in 12 patients $(36.36 \%)$. The seizures in all patients were generalized tonic-clonic and developed within 24hours post tramadol ingestion. Patients with seizures had significantly lower GCS and severe PSS than patients without seizures. Meanwhile, no statistical significant difference was observed between the two studied groups as regards vital data (blood pressure, pulse rate, respiratory rate and temperature), oxygen saturation, arterial blood gases and $\mathrm{pH}$. 
Table (2): Clinical findings of the studied patients $(n=33)$ on admission

\begin{tabular}{|c|c|c|c|c|c|c|}
\hline Variables & & $\begin{array}{l}\text { Group I } \\
\text { Seizure } \\
\text { group } \\
(\mathrm{n}=12) \\
\end{array}$ & \begin{tabular}{|l|} 
Group II \\
Non-seizure \\
group \\
$(\mathrm{n}=21)$ \\
\end{tabular} & \begin{tabular}{|l|} 
Total studied \\
patients \\
$(n=33)$
\end{tabular} & $\begin{array}{l}\text { Test } \\
\text { statistic }\end{array}$ & P value \\
\hline \multirow{3}{*}{$\begin{array}{l}\text { GCS } \\
(3-15)\end{array}$} & Range & $3-8$ & $3-11$ & $3-11$ & \multirow{3}{*}{$\begin{array}{l}Z_{\mathrm{MW}}= \\
-3.948\end{array}$} & \multirow[t]{3}{*}{$<0.001 *$} \\
\hline & Median & 3 & 9 & 8 & & \\
\hline & IQR & $3.0-4.0$ & $8.0-10.0$ & $3.0-9.0$ & & \\
\hline \multirow{2}{*}{$\begin{array}{l}\text { PSS } \\
\mathbf{N}(\%)\end{array}$} & Moderate & $0(0 \%)$ & $12(57.1 \%)$ & $12(36.4 \%)$ & \multirow{2}{*}{$\begin{array}{l}X^{2} \text { ChS } \\
8.448\end{array}$} & \multirow[t]{2}{*}{$=<0.002 *$} \\
\hline & Severe & $12(100 \%)$ & $9(42.9 \%)$ & $21(63.6 \%)$ & & \\
\hline \multirow{3}{*}{$\begin{array}{l}\text { Pulse Rate } \\
\text { (beats/min) } \\
\mathbf{N}(\%) \\
\end{array}$} & Normal & $9(75.0 \%)$ & $12(57.1 \%)$ & $21(63.6 \%)$ & \multirow{3}{*}{$\begin{array}{l}X_{\mathrm{FE}}^{2}= \\
1.738\end{array}$} & \multirow[t]{3}{*}{0.487} \\
\hline & Bradycardia & $0(0.0 \%)$ & $3(14.3 \%)$ & $3(9.1 \%)$ & & \\
\hline & Tachycardia & $3(25.0 \%)$ & $6(28.6 \%)$ & $9(27.3 \%)$ & & \\
\hline \multirow{2}{*}{\begin{tabular}{|l} 
Blood Pressure \\
$(\mathbf{m m H g})$ \\
$\mathbf{N}(\%)$
\end{tabular}} & Normal & $9(75.0 \%)$ & $21(100.0 \%)$ & $30(90.9 \%)$ & \multirow{2}{*}{$\begin{array}{l}\mathrm{X}_{\mathrm{ChS}}^{2} \\
3.146\end{array}$} & \multirow[t]{2}{*}{$=0.076$} \\
\hline & Hypotensive & $3(25.0 \%)$ & $0(0.0 \%)$ & $3(9.1 \%)$ & & \\
\hline \multirow{2}{*}{$\begin{array}{l}\text { Respiratory Rate } \\
\text { (breaths/min) } \\
\text { N }(\%)\end{array}$} & Normal & $6(50.0 \%)$ & $9(42.9 \%)$ & $15(45.5 \%)$ & \multirow{2}{*}{$\begin{array}{l}X^{2} \text { ChS } \\
0.157\end{array}$} & \multirow[t]{2}{*}{$=0.692$} \\
\hline & Bradypnea & $6(50.0 \%)$ & $12(57.1 \%)$ & $18(54.5 \%)$ & & \\
\hline \multirow{2}{*}{$\begin{array}{l}\text { Temperature } \\
\left({ }^{\circ} \mathrm{C} \text { oral }\right) \\
\mathrm{N}(\%)\end{array}$} & Normal & $9(75.0 \%)$ & $18(85.7 \%)$ & $27(81.8 \%)$ & \multirow{2}{*}{$\begin{array}{l}\mathrm{X}_{\mathrm{ChS}}^{2} \\
0.089\end{array}$} & \multirow{2}{*}{$=0.765$} \\
\hline & Fever & $3(25.0 \%)$ & $3(14.3 \%)$ & $6(18.2 \%)$ & & \\
\hline
\end{tabular}

GCS= Glasgow coma scale, $\mathrm{PSS}=$ Poisoning severity score, $\mathrm{IQR}=$ interquartile range, $Z_{\mathrm{MW}}=$ Mann-Whitney test, $\mathbf{X}_{\mathrm{ChS}}=$ Pearson's Chi-square test for association, $\mathbf{X}_{\mathrm{FE}}^{2}=$ Fisher's Exact test, * significant at $p<0.05$

Moreover, the median of administered naloxone dose in the studied patients was $2.4 \mathrm{mg}$ (range 0.4 $10.8 \mathrm{mg})$. The administered naloxone doses were significantly higher in patients with seizures than in patients without seizures with median of 6.8 vs $2.4 \mathrm{mg}$ respectively $(\mathrm{p}<0.017)$. Only three patients $(9.1 \%)$ required endotracheal intubation with no significant difference between the two studied groups (table 3).

As shown in table 3 , the mean serum $\mathrm{S} 100 \mathrm{~B}$ of the studied patients was $0.50 \pm 0.13(0.30-0.81 \mu \mathrm{g} / \mathrm{L})$. It was significantly higher than that of the control group $0.08 \pm 0.02(0.02-0.1$ $\mu \mathrm{g} / \mathrm{L})$. Also, the mean serum S100B was significantly higher in patients with seizures than in patients without seizures ( $\quad$ < 20.001$)$. 
Table (3): Laboratory findings on admission, endotracheal intubation and administered naloxone dose of the studied patients $(n=33)$

\begin{tabular}{|c|c|c|c|c|c|c|}
\hline Variables & & $\begin{array}{l}\text { Group I } \\
\text { Seizure } \\
\text { group } \\
(\mathbf{n}=12)\end{array}$ & $\begin{array}{l}\text { Group II } \\
\text { Non-seizure } \\
\text { group } \\
(\mathbf{n}=21)\end{array}$ & $\begin{array}{l}\text { Total } \\
\text { studied } \\
\text { patients } \\
(n=33)\end{array}$ & $\begin{array}{l}\text { Test } \\
\text { statistic }\end{array}$ & P-value \\
\hline \multirow{3}{*}{$\begin{array}{l}\text { Oxygen } \\
\text { saturation } \\
\text { N }(\%)\end{array}$} & $\begin{array}{l}\text { Normal } \\
(\geq 95 \%)\end{array}$ & $3(25.0 \%)$ & $9(42.9 \%)$ & $12(36.4 \%)$ & \multirow{3}{*}{$\begin{array}{l}\mathrm{X} 2_{\mathrm{FE}}= \\
4.519\end{array}$} & \multirow[t]{3}{*}{0.090} \\
\hline & $\begin{array}{l}\text { Mild hypoxia } \\
(90-94 \%)\end{array}$ & $3(25.0 \%)$ & $9(42.9 \%)$ & $12(36.4 \%)$ & & \\
\hline & $\begin{array}{l}\text { Severe } \\
\text { hypoxia } \\
(<75 \%)\end{array}$ & $6(50.0 \%)$ & $3(14.3 \%)$ & $9(27.3 \%)$ & & \\
\hline \multirow{3}{*}{ pH } & Range & $6.90-7.32$ & $6.85-7.35$ & $6.85-7.35$ & \multirow{3}{*}{$\begin{array}{l}\mathrm{Z}_{\mathrm{MW}}= \\
-1.014\end{array}$} & \multirow[t]{3}{*}{0.310} \\
\hline & Median & 7.09 & 7.23 & 7.17 & & \\
\hline & IQR & $6.95-7.25$ & $7.03-7.28$ & $7.00-7.28$ & & \\
\hline \multirow{4}{*}{$\begin{array}{l}\text { Acid-base } \\
\text { status } \\
\text { N }(\%)\end{array}$} & Normal & $0(0.0 \%)$ & $3(14.3 \%)$ & $3(9.1 \%)$ & \multirow{4}{*}{$\begin{array}{l}\mathrm{X} 2_{\mathrm{FE}}= \\
4.018\end{array}$} & \multirow{4}{*}{0.252} \\
\hline & $\begin{array}{l}\text { Metabolic } \\
\text { acidosis }\end{array}$ & $3(25.0 \%)$ & $6(28.6 \%)$ & $9(27.3 \%)$ & & \\
\hline & $\begin{array}{l}\text { Respiratory } \\
\text { acidosis }\end{array}$ & $9(75.0 \%)$ & $9(42.9 \%)$ & $18(54.5 \%)$ & & \\
\hline & $\begin{array}{l}\text { Respiratory \& } \\
\text { metabolic } \\
\text { acidosis } \\
\end{array}$ & $0(0.0 \%)$ & $3(14.3 \%)$ & $3(9.1 \%)$ & & \\
\hline \multicolumn{2}{|c|}{ Serum S100BRange } & $0.38-0.81$ & $0.30-0.60$ & $0.30-0.81$ & \multirow{2}{*}{$\begin{array}{l}t= \\
-4.593\end{array}$} & \multirow{2}{*}{$\begin{array}{l}< \\
0.001 *\end{array}$} \\
\hline level $(\mu \mathrm{g} / \mathrm{L})$ & Mean \pm SD & $0.61 \pm 0.13$ & $0.44 \pm 0.08$ & $0.50 \pm 0.13$ & & \\
\hline \multirow{2}{*}{$\begin{array}{l}\text { Endotracheal } \\
\text { Intubation } \\
\text { N }(\%)\end{array}$} & No & $9(75.0 \%)$ & $21(100.0 \%)$ & $30(90.9 \%)$ & \multirow{2}{*}{$\begin{array}{l}\mathrm{X} 2_{\mathrm{ChS}}= \\
3.146\end{array}$} & \multirow[t]{2}{*}{$=0.076$} \\
\hline & Yes & $3(25.0 \%)$ & $0(0 \%)$ & $3(9.1 \%)$ & & \\
\hline \multirow{3}{*}{$\begin{array}{l}\text { Administered } \\
\text { Naloxone dose } \\
\text { (mg) }\end{array}$} & Range & $0.4-10.8$ & $1.2-4.4$ & $0.4-10.8$ & \multirow{3}{*}{$\mid \begin{array}{l}\mathrm{Z}_{\mathrm{MW}} \\
2.377\end{array}$} & \multirow[t]{3}{*}{$=0.017 *$} \\
\hline & Median & 6.8 & 2.4 & 2.4 & & \\
\hline & IQR & $2.8-10$ & $1.2-4.0$ & $1.2-4.8$ & & \\
\hline
\end{tabular}

IQR: interquartile range, $\mathbf{Z}_{\mathrm{MW}}=$ Mann-Whitney test, $\mathbf{X}^{2}{ }_{\mathrm{ChS}}=$ Pearson's Chi-square test for association, $X^{2}{ }_{F E}=$ Fisher's Exact test, * Significant at $p<0.05$.

Likewise, serum S100B showed significant positive correlations with delay time, PSS, administered naloxone dose and a significant negative correlation with GCS. However, no significant correlations could be detected between serum S100B and ingested tramadol dose, intubated cases or hospitalization period (table 4). 
Table (4): Spearman's correlation between serum S100B with some relevant variables

\begin{tabular}{|c|c|c|}
\hline \multicolumn{2}{|l|}{ Variables } & Serum S100B \\
\hline \multirow{2}{*}{ Delay time (hours) } & $\mathrm{r}$ & 0.551 \\
\hline & $\mathrm{P}$ & $0.001 *$ \\
\hline \multirow{2}{*}{ GCS } & $\mathrm{r}$ & -0.727 \\
\hline & $\mathrm{P}$ & $<0.001^{*}$ \\
\hline \multirow{2}{*}{ PSS } & $\mathrm{r}$ & 0.636 \\
\hline & $\mathrm{P}$ & $<0.001 *$ \\
\hline \multirow{2}{*}{$\begin{array}{l}\text { Ingested tramadol dose } \\
(\mathbf{m g})\end{array}$} & $\mathrm{r}$ & 0.319 \\
\hline & $\mathrm{P}$ & 0.070 \\
\hline \multirow{2}{*}{$\begin{array}{c}\text { Hospitalization period } \\
\text { (hours) }\end{array}$} & $\mathrm{r}$ & 0.277 \\
\hline & $\mathrm{P}$ & 0.396 \\
\hline \multirow{2}{*}{$\begin{array}{c}\text { Administered naloxone dose } \\
\text { (mg) }\end{array}$} & $\mathrm{r}$ & 0.439 \\
\hline & $\mathrm{P}$ & $0.011 *$ \\
\hline \multirow{2}{*}{ Intubated cases } & $\mathrm{r}$ & 0.342 \\
\hline & $\mathrm{P}$ & 0.051 \\
\hline
\end{tabular}

GCS: Glascow coma scale, PSS: poisoning severity score

r: correlation coefficient of Spearman's correlation, $*$ significant at $\mathbf{p}<0.05$.

Table (5) and Fig (1) showed the results of analysis of receiver operating characteristics (ROC) curve of serum $\mathrm{S} 100 \mathrm{~B}$ for predicting seizure occurrence in acute tramadol poisoning. The serum S100B level had $75.00 \%$ sensitivity and $95.24 \%$ specificity at cut-off value $>0.58 \mu \mathrm{g} / \mathrm{L}$ and showed AUC $=0.863$, with a $95 \%$ confidence interval (p <0.001).

Table (5): Best cutoff, sensitivity, specificity, and area under the curve (AUC) values of serum S100B level for predicting the occurrence of seizure (95\% confidence interval (CI))

\begin{tabular}{|l|l|}
\hline $\begin{array}{l}\text { Area under the ROC curve } \mathbf{( 9 5 \%} \\
\text { CI) }\end{array}$ & $\begin{array}{l}0.863 \quad 0.699 \quad \text { to } \\
0.957)\end{array}$ \\
\hline z statistic & 4.508 \\
\hline P value & $<0.001 *$ \\
\hline Best cut off value $(\boldsymbol{\mu g} / \mathbf{L})$ & $>0.58$ \\
\hline Sensitivity & $75.00 \%$ \\
\hline Specificity & $95.24 \%$ \\
\hline Positive predictive value & $90.00 \%$ \\
\hline Negative predictive value & $86.96 \%$ \\
\hline
\end{tabular}

* Significant at $\mathrm{p}<0.05$ 


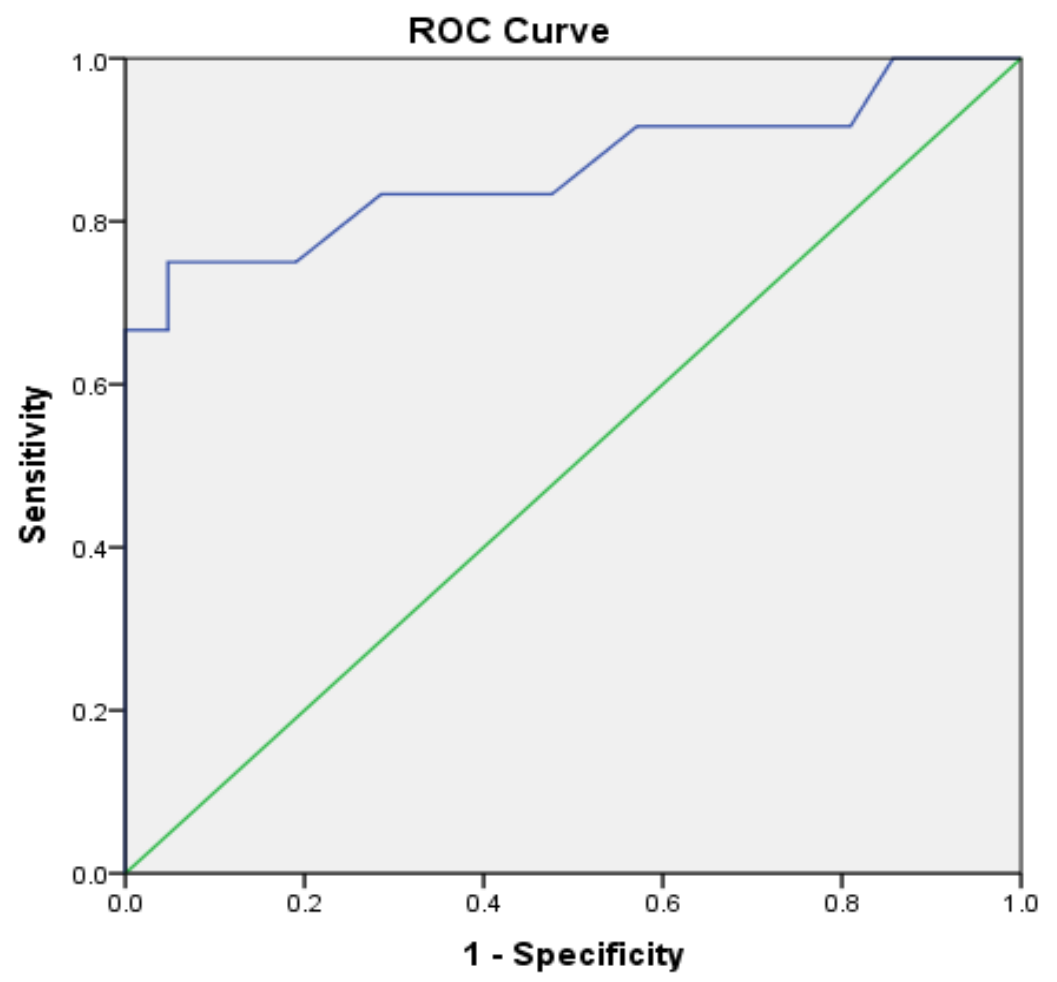

Figure (1): ROC curve analysis of serum S100B level as a predictor of occurrence of seizure. Area under the curve $=0.863, \mathrm{P}<0.001 \%$, sensitivity $75.00 \% \&$ specificity $95.24 \%$ at cut off value $>0.58 \mu \mathrm{g} / \mathrm{L}$.

\section{DISCUSSION}

Tramadol is a frequently used opioid for management of moderate to severe pain (Pothiawala \& Ponampalam, 2011). Although, tramadol is considered a safe analgesic but recently, reports of tramadol abuse, dependence, poisoning and deaths have been increasing, as it is still the only clinically accessible opioid in most countries (Brinker et al., 2002; Tjaderborn et al., 2007 and Elkalioubie et al., 2011).

Seizures are one of the most serious manifestations of tramadol therapeutic use, abuse or overdose. Seizures may induce complications such as hypoxia, trauma, muscular damage, rhabdomyolysis, renal failure and even death (Shadnia et al., 2012; Eizadi-Mood et al., 2014 and Rahimi et al., 2014). This study showed that seizures were significantly reported in young adult males aged from 21 - 40 years, which is in line with the studies of Talaie et al. (2009), Petramfar \& Haghighi, (2010) and Ahmadi et al. (2012). This could be attributed to, the more consumption of tramadol by male subjects to improve the premature ejaculatory function and extend the sexual orgasm (Fawzi, 2010). However, other studies did not demonstrate any significant difference in seizure incidence as regards age and gender (Taghaddosinejad et al., 2011 and Rahimi et al., 2014).

The current study demonstrated that the ingested tramadol dose in seizure group ranged from 200 to 3000 $\mathrm{mg}$ with median of $1200 \mathrm{mg}$, which was significantly higher than cases without seizures. This result partially agreed with Taghaddosinejad et al. (2011) who reported that the mean ingested tramadol dose accompanied 
with seizures was $1511 \pm 135.3$ (range 200-7000 mg). Meanwhile, Rahimi et al. (2014), who studied patients with acute tramadol poisoning in Tehran, found significant decrease of ingested dose in cases with seizures than those without seizures $(1395.7 \pm 218.3$ vs. $2500.7 \pm 390 \mathrm{mg}$ respectively). This discrepancy between the obtained results and those of Rahimi et al. could be attributed to genetic polymorphism. On the other hand, Talaie et al. (2009) demonstrated that there was no significant difference between patients with and without seizures in ingested tramadol dose and they attributed that to alcohol co-ingestion in cases with seizures.

Oral route was the only route of intoxication in this study and this is in accordance with the results of other studies (Shadnia et al., 2012; Hassanian-Moghaddam et al., 2013 and Hassanian-Moghaddam et al., 2015) which showed that oral route is the most common route of tramadol administration. This can be explained by the availability of tramadol oral forms as reported by Fouad et al. (2015).

The present study revealed that, the mean delay time was longer in seizure group than in non-seizure group $(6.3 \pm$ 2.6 vs $4.8 \pm 1.6$ hours respectively). This partially agreed with Rahimi et al. (2014) who demonstrated significant increase in delay time in seizure cases than cases without seizure $(330.3 \pm 53.5$ vs. $257.3 \pm 30.1 \mathrm{~min}$ respectively).

Additionally, intentional poisoning was the most common mode of poisoning followed by drug abuse in our study. This finding is in agreement with Shadnia et al. (2008), Taghaddosinejad et al. (2011) and
Rahimi et al. (2014). The median of the hospitalization period was 72 hours (range: 24 - 125 hours) which was in line with Ghasempouri et al. (2014) who found that the mean of hospitalization period was 1.24 day (range: 1 - 5 days). There was no significant difference between both groups as regards manner of poisoning and hospitalization period, which agreed with the results of Rahimi et al. (2014).

The majority of patients in the present study had signs of respiratory depression as bradypnea, respiratory acidosis in $54.5 \%$ per each and hypoxia in $63.7 \%$ of the studied patients. This finding was partially in accordance with Hassanian-Moghaddam et al. (2013) and Rahimi et al. (2014) who demonstrated respiratory problems as dyspnea and decreased partial pressure of oxygen in all tramadol-poisoned patients due to tramadol induced respiratory depression. Tachycardia was recorded in $27.3 \%$ of patients in this study that could be attributed to noradrenergic reuptake inhibitory effects of tramadol. This result coincided with Ryan \& Isbister (2015) who found tachycardia in $38 \%$ of patients. However, no significant difference could be detected between both groups regarding vital data, oxygen saturation, arterial blood gases and $\mathrm{pH}$, which coincide with the results of Rahimi et al. (2014).

Seizures were recorded in $36.36 \%$ of cases in the current study. This was comparable with previous studies which reported that seizures develop in approximately one-third of cases with tramadol overdose (Shadnia et al., 2008 and Taghaddosinejad et al., 2011). Despite, Ryan \& Isbister (2015) recorded lower frequency of 
seizures in tramadol poisoned patients (11\%), but, other studies by JovanovicCupic et al. (2006), Talaie et al. (2009) and Rahimi et al. (2014) recorded higher seizure frequency $(54.4 \%, \quad 46.2 \%, \quad$ and $47.9 \%$ respectively) in acute tramadol poisoned patients.

This variation of seizure incidence could be attributed to many factors such as the different affinity of tramadol two enantiomers $(+) \&(-)$ for the opioid receptors and monoamines reuptake (Potschka et al., 2000 and Beyaz et al., 2016). Additionally, tramadol is metabolized by cytochrome P450 (mainly CYP2D6 isomer) to its active metabolite (Odesmethyltramadol) which has serotonergic activity and can induce seizures. The impact of CYP2D6 polymorphism plays an important role in the different clinical presentations of tramadol toxicity (Becquemont, 2009 and Boostani \& Derakhshan, 2012).

This explanation could be supported by the results of Ibrahim et al. (2015) who found a significant relation between tramadol's metabolite level and clinical severity among tramadol intoxicated Egyptian patients as $60 \%$ of the studied patients were extensive metabolizers, $23 \%$ were ultrarapid and $17 \%$ of cases were poor metabolizers.

Patients with seizures had significantly low GCS with median of 3 (range $3-8$ ) and severe PSS than patients without seizures. Likewise, Fouad et al. (2015) reported that $85.7 \%$ of intensive care cases and $44.4 \%$ of non-survivor cases of tramadol poisoned patients had seizures and their GCS were between 3 and 8.76. Hence, this extreme drowsiness and coma may occur following seizures
(Shadnia et al., 2008).

In the present study, the administered naloxone dose was significantly higher in seizure group than in non-seizure group. The seizureogenic effect of naloxone in tramadol overdose was controversy. Some studies demonstrated that naloxone markedly increased the incidence of seizures (Van de Kamp, 1986 and Taghaddosinejad et al., 2011). Furthermore, Farzaneh et al. (2012) reported that naloxone could increase the seizurogenic effect of tramadol in high-risk patients. On the other hand, some studies found that naloxone might reduce tramadol induced seizure effects (Yang et al., 2010 and Eizadi-Mood et al., 2014). Although, the neuroprotective effect of naloxone was poorly understood, the antagonistic effect on opioid receptors could reduce cytokines production and glial activation (Liu \& Hong, 2003). However, Omrani et al. (2007) revealed that naloxone did not alter the seizurogenic effects of tramadol.

To the best of the authors' knowledge, the present study was the first study to assess the role of S100B protein as a predictor of tramadol induced seizure. The current study demonstrated that, patients with acute tramadol overdose with and without seizures had significantly higher serum S100B levels when compared to the control group. Similarly, Ambrozic et al. (2008) found that serum S100B was significantly higher in acute benzodiazepine patients when compared to control group.

Moreover, patients with seizures had significantly higher serum S100B than those without seizures. Many previous studies have documented elevation of serum S100B in patients 
with seizures and epilepsy (Kacinski et al., 2012 and Dogan et al., 2013). This could be explained by astrocytic reaction aiming to promote neuronal stability and protection (Oses et al., 2004). Elevated S100B serum levels may be an early event in seizure development because of blood brain barrier (BBB) leakage (Marchi et al., 2007).

Furthermore, serum S100B might be released to peripheral circulation as a result of hypoxic brain damage. Since, serum S100B is found in high concentration of astroglial cells, which are very sensitive to hypoxic stress. Therefore, serum S100B may indirectly reflect neuronal damage (Bottiger et al., 2001). This could be supported by significant increase of serum S100B in patients who had low Glascow coma scale (GCS) and severe poisoning severity score (PSS) on admission. Additionally, the majority of patients in the present study had signs of respiratory depression and hypoxia. Previous studies have reported the diagnostic and prognostic value of serum S100B in brain hypoxia due to carbon monoxide poisoning, benzodiazepine overdose, organophosphate poisoning and aluminum neurotoxicity (Ambrozic et al., 2008; Yardan et al., 2009 and Cakir et al., 2010). The role of tissue hypoperfusion, in the elevation of serum S100B, in the current study was unlikely as the majority of cases (90.9\%) had normal blood pressure.

Moreover, ROC curve analysis showed that high serum S100B might be useful in prediction of tramadolinduced seizure. Above the cutoff value of $0.58 \mu \mathrm{g} / \mathrm{L}$, serum S100B had $75 \%$ sensitivity and $95.24 \%$ specificity. This means that above level of 0.58 $\mu \mathrm{g} / \mathrm{L}, \mathrm{S} 100 \mathrm{~B}$ could predict seizures in $75 \%$ of cases and below these level, seizures could be excluded in $95.24 \%$ of cases.

\section{CONCLUSIONS:}

Although tramadol seems to be a safe analgesic, it might cause subtle brain injury. Serum S100B is a good predictor of tramadol-induced seizure and it could be used as a useful biomarker to assess clinical severity in acute tramadol overdose. Additionally, young adult males increased both of ingested tramadol doses and administered naloxone dose, decreased level of consciousness and severe tramadol poisoning were considered risk factors of tramadol-induced seizure.

\section{LIMITATION OF THE STUDY\& RECOMMENDATIONS}

One of the limitations in this study was our inability to follow up the patients which prevented us from evaluation of the prognostic value of serum S100B in delayed neurological sequelae after patient's discharge. Other limitations are the small sample size and absent tramadol blood level which prevented us from clarifying its role in seizure incidence. Therefore, we suggested performing a larger prospective study for acute tramadol poisoned patients taking into consideration a good follow up to evaluate the role of serum S100B as a diagnostic and prognostic biomarker. Also, we suggested serial measurements of serum S100B to be performed to verify the best time of sampling in acute tramadol poisoning. 


\section{REFERENCES}

Afshari R. and Ghooshkhanehee $\mathbf{H}$. (2009): Tramadol overdose induced seizure, dramatic rise of CPK and acute renal failure. J Pak Med Assoc.; 59(3): 178.

Ahmadi H., Rezaie M. and Hoseini J. (2012): Epidemiology analysis of poisonings with tramadol. $\mathrm{J}$ Forensic Res.; 3(6): 151.

Akdemir H. U., Yardan T., Kati C., Duran L., Alacam H., Yavuz Y. and Okuyucu A. (2014): The role of S100B protein, neuron-specific enolase, and glial fibrillary acidic protein in the evaluation of hypoxic brain injury in acute carbon monoxide poisoning. Hum Exp Toxicol.; 33(11): 1113-1120.

Ambrozic J., Bunc M., Osredkar J. and Brvar M. (2008): S100B protein in benzodiazepine overdose. Emerg Med J.; 25(2): 9092.

\section{Becquemont}

L.

(2009):

Pharmacogenomics of adverse drug reactions: practical applications and perspectives. Pharmacogenomics; 10: 961-969.

Beyaz S. G., Sonbahar T., Bayar F. and Erdem A. F. (2016): Seizures associated with low-dose tramadol for chronic pain treatment. Anesth Essays Res.; 10(2): 376-378.

Boostani R. and Derakhshan S. (2012): Tramadol induced seizure: A 3-year study. Caspian J Intern Med.; 3(3): 484-487.

Bottiger B. W., Mobes S., Glatzer R., Bauer H., Gries A., Bartsch P., Motsch J. and Martin E. (2001): Astroglial protein $\mathrm{S}-100$ is an early and sensitive marker of hypoxic brain damage and outcome after cardiac arrest in
humans.Circulation.;

103(22): 2694-2698.

Brinker A., Bonnel R. A. and Beitz J. (2002): Abuse, dependence, or withdrawal associated with tramadol. Am J Psychiatry.; 159(5): 881.

Cakir Z., Aslan S., Umudum Z., Acemoglu H., Akoz A., Turkyilmaz S. and Ozturk N. (2010): S-100 beta and neuronspecific enolase levels in carbon monoxide-related brain injury. Am J Emerg Med.; 28(1): 61-67.

Dawson-Saunders B. and Trapp $R$. (2001): Basic and clinical biostatics. Lang Medical Book,3rd ed. McGrow Hill Medical Publishing Division, NewYork. Pp: $161-218$.

DeLong E. R., DeLong D. M. and Clarke-Pearson D. L. (1988): Comparing the areas under two or more correlated receiver operating characteristic curves: a nonparametric approach. Biometrics; 44:837-845.

Dogan F. S., Altinok A. D., Onur O. E., Guneysel O. and Akoglu $H$. (2013): S100B protein levels in patients admitted to an emergency service due to seizures. Marmara Med J; 26(2): 90-93.

Duke A. N., Bigelow G. E., Lanier R. K. and Strain E. C. (2011): Discriminative stimulus effects of tramadol in humans. $\mathbf{J}$ Pharmacol Exp Ther.; 338(1): 255262.

\section{Eizadi-Mood}

D., Sabzghabaee

N., Ozcan

M., Mirmoghtadaee

A. and Hedaaiaty M. (2014): Does naloxone prevent seizure in tramadol intoxicated patients?. Int J Prev Med.; 5(3): 302-307. 
Elkalioubie A., Allorge D., Robriquet L., Wiart J. F., Garat A., Broly F. and Fourrier F. (2011): Nearfatal tramadol cardiotoxicity in a CYP2D6 ultrarapid metabolizer. Eur J Clin Pharmacol.; 67(8): 855858.

El-Masry M. K. and Tawfik H. M. (2013): 2011 Annual report of the poison control centre of Ain Shams University Hospital, Cairo, Egypt. Ain Shams J Forensic Med Clin Toxicol; 20: 10-17.

Farzaneh E., Mostafazadeh B. and Mehrpour O. (2012): Seizurogenic effects of low-dose naloxone in tramadol overdose. IJPT.; 11(1): 6-9.

Fawzi M. (2010): Some medicolegal aspects concerning tramadol abuse: The new Middle East youth plague 2010. An Egyptian overview. Egyptian J Forensic Sci; 1(2): 99102.

Fouad S., Hassan N., Nassief N., ElHalawany $F$. and Hussien $R$. (2015): Critical score as a predictor for progression of tramadol intoxication. J Clin Toxicol.; 5(3): 249.

Ghasempouri K., Khosrojerdi H. and Khadem-Rezaiyan M. (2014): Tramadol overdose induced transient paresthesia and decreased muscle strength: a case series. Asia Pac J Med Toxicol.; 3(2): 59-63.

Hassanian-Moghaddam H., Farajidana H., Sarjami S. and Owliaey H. (2013): Tramadolinduced apnea. AmJ Emerg Med.; 31(1): 26-31.

Hassanian-Moghaddam H., Farnaghi F. and Rahimi M. (2015): Tramadol overdose and apnea in hospitalized children, a review of 20 cases. Res Pharm Sci.; 10(6):
544-552.

Ibrahim S. F, Ali M. M., Gouda A. S. and Rashed L. A. (2015): Association between the severity of tramadol toxicity and some CYP2D6 allelic variants in Egyptian tramadol intoxicated patients. Emergency Med.; 5(6): 303.

Iravani F. S., Akhgari M., Jokar F. and Bahmanabadi L. (2010): Current trends in tramadol-related fatalities, Tehran, Iran 20052008. Subst Use Misuse; 45(13): 2162-2171.

Jovanovic-Cupic V., Martinovic Z. and Nesic N. (2006): Seizures associated with intoxication and abuse of tramadol. ClinToxicol.; 44(2):143-146.

Kacinski M., Budziszewska B., Lason W., Zajac A., Skowronek-Bala B., Leskiewicz M., Kubik A. and Basta-Kaim A. (2012): Level of S100B protein, neuron specific enolase, orexin $\mathrm{A}$, adiponectin and insulin-like growth factor in serum of pediatric patients suffering from sleep disorders with or without epilepsy. Pharmacol Rep.; 64(6): 1427-1433.

Liu B. and Hong J. S. (2003): Role of microglia in inflammationmediated neurodegenerative diseases: Mechanisms and strategies for therapeutic intervention. J Pharmacol Exp Ther.; 304(1): 1-7.

Liu H., Zhang Y., Ren Y. B., Kang J., Xing J., Qi Q. H., Gao D. N., Ma T., Liu X. W. and Liu Z. (2015): Serum S100B level may be correlated with carbon monoxide poisoning. Int Immunopharmacol.; 27(1): 69-75.

Majidi M. and Nekouei-Fard S. 
(2014): Refractory seizures in tramadol poisoning: a case report. IJT.; 8(26): 1157-1159.

Marchi N., Angelov L., Masaryk T., Fazio V., Granata T., Hernandez N., Hallene K., Diglaw T., Franic L., Najm I. and Janigro D. (2007): Seizure-promoting effect of blood-brain barrier disruption. Epilepsia; 48(4): $\quad 732-$ 742.

Nasouhi S., Talaie

A., Aghapour

M., Khorasani

H., Pajoumand

S., Rahimi

G., Mashayekhian

A.

M., Aghabiklooei A., Razi P. and Mahdavinejad A. (2015): Нypo and

hyperglycemia among tramadol overdose patients in Loghman Hakim Hospital, Tehran, Iran. Pak J Pharm Sci.; 28(6): 1959-1963.

Omrani A., Ghadamia M. R., Fathia N., Tahmasian M., Fathollahi Y. and Touhidi A. (2007): Naloxone improves impairment of spatial peformance induced by pentylentetrazol. Neuroscience; 145(3): 824-831.

Oses J. P., Leke R., Portela L. V., Lara D. R., Schmidt A. P., Casali E. A., Wofchuk S., Souza D. O. and Sarkis J. J. (2004): Biochemical brain markers and purinergic parameters in rat CSF after seizure induced by pentylenetetrazol. Brain Res Bull.; 64(3): 237-242.

Petramfar P. and Haghighi A. B. (2010): Tramadol induced seizure: report of 106 patients. IRCMJ.; 12(1): 49-51.

Pothiawala S. and Ponampalam R. (2011): Tramadol overdose: a case report. Proceedings of Singapore Healthcare; 20(3): 219-223.
Potschka H., Friderichs E. and Loscher W. (2000): Anticonvulsant and proconvulsant effects of tramadol, its enantiomers and its M1 metabolite in the rat kindling model of epilepsy. $\mathrm{Br} \mathrm{J}$ Pharmacol.; 131:203-212.

Rahimi H. R., Soltaninejad K. and Shadnia S. (2014): Acute tramadol poisoning and its clinical and laboratory findings. J Res Med Sci.;19(9): 855-859.

Ryan N. M. and Isbister G. K. (2015): Tramadol overdose causes seizures and respiratory depression but serotonin toxicity appears unlikely. ClinToxicol (Phila); 53(6): 545-550.

Shadnia S., Brent J., MousaviFatemi K., Hafezi P. and Soltaninejad K. (2012): Recurrent seizures in tramadol intoxication: implications for therapy based on 100 patients. Basic Clin Pharmacol Toxicol.; 111(2): 133-136.

Shadnia S., Soltaninejad K., Heydari K., Sasanian G. and Abdollahi M. (2008): Tramadol intoxication: a review of 114 cases. Hum ExpToxicol.; 27(3): 201-205.

Sykes O. T. and Walker E. (2016): The neurotoxicology of carbon monoxide-Historical perspective and review. Cortex; 74: 440-448.

Taghaddosinejad F., Mehrpour O., Afshari R., Seghatoleslami A., Abdollahi M. and Dart R. C. (2011): Factors related to seizure in tramadol poisoning and its blood concentration. J Med Toxicol.; 7(3): 183-188.

Talaie

H., Panahandeh

R., Fayaznouri M., Asadi Z. and Abdollahi M. (2009): Doseindependent occurrence of seizure with tramadol. J Med Toxicol.; 
5(2): 63-67.

Tjaderborn M., Jonsson A. K., Hagg S. and Ahlner J. (2007): Fatal unintentional intoxications with tramadol during 1995-2005. Forensic Sci Int.; 173: 107-111.

Van de Kamp J. L. (1986): The effect of naloxone administration on pregnancy-associated seizures. Life Sci.; 38: 1899-1905.

Watson W. A., Litovitz T. L., Rodgers G. C. Jr., KleinSchwartz W., Youniss J., Rose S. R., Borys D. and May M. E. (2003): 2002 Annual report of the American Association of Poison Control Centers Toxic Exposure
Surveillance System. Am J Emerg Med.; 21(5): 353-421.

Yang L., Li F., Ge W., Mi C., Wang R. and Sun R. (2010): Protective effects of naloxone in two-hit seizure model. Epilepsia; 51: 344353.

Yardan T., Cevik Y., Donderici O., Kavalci C., Yilmaz F. M., Yilmaz G., Vural K., Yuzbasioglu Y., Gunaydin Y. K. and Sezer A. A. (2009): Elevated serum S100B protein and neuron-specific enolase levels in carbon monoxide poisoning. Am J Emerg Med.; 27(7): 838-842. 


\section{الملخص العربي}

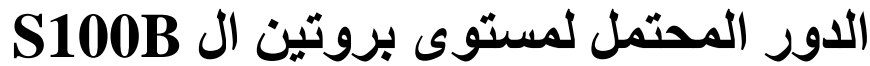

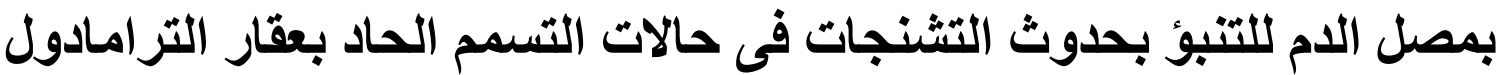

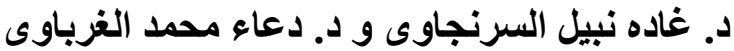

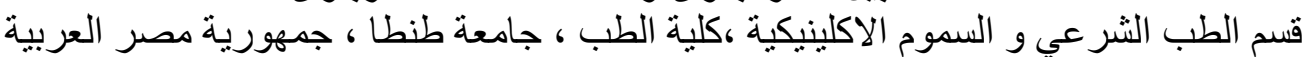

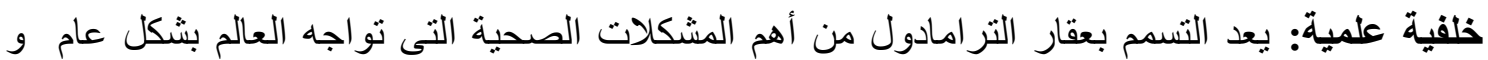

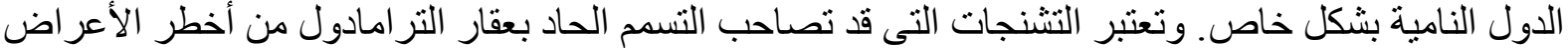

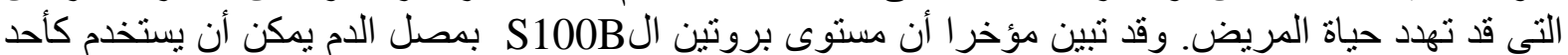

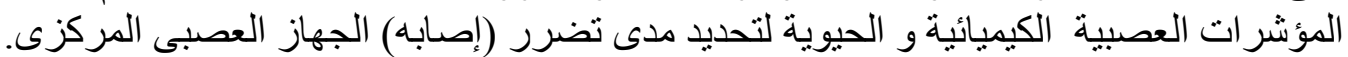
الهدف من البحث: تقييم دور بروتين S100B عند دخول المريض كمؤشر لاحتماليه حدوث التشنجات

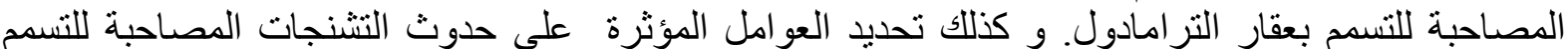

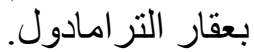

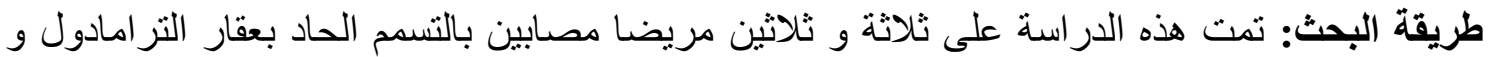

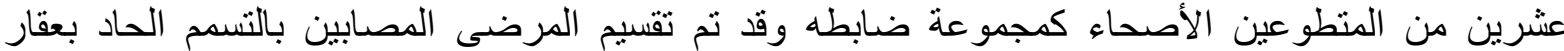

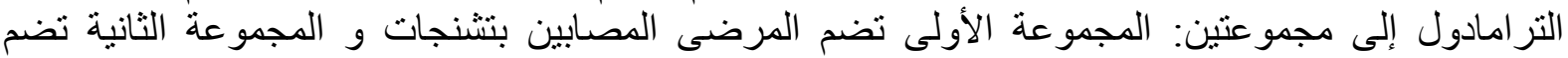

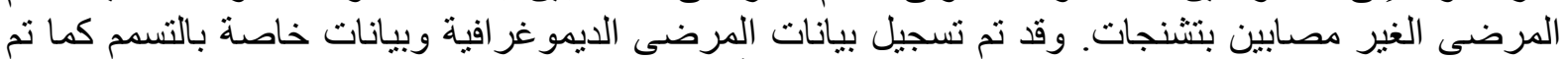
فحص المرضى و عمل التحاليل اللازمة عند الدخول و أيضاً تم قياس مستوى بروتين S100B بالدم.

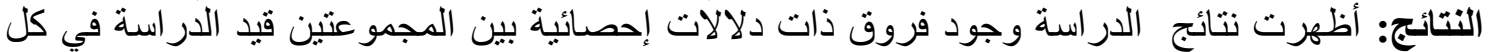

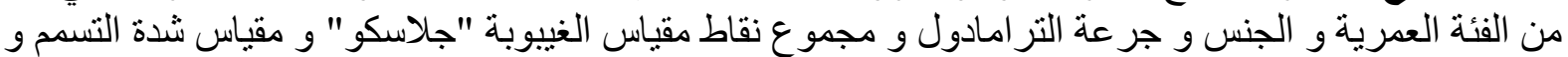

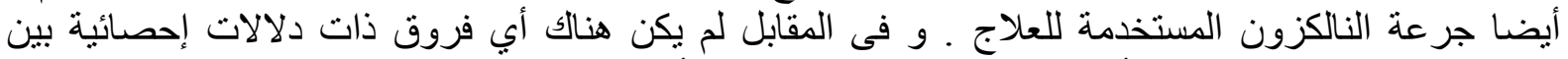

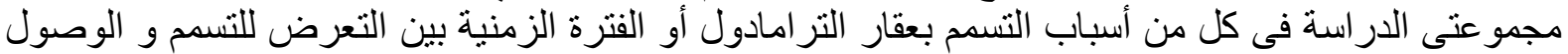
للمستشفى أو العلامات الحيوية للمريض أو مستوى تتبع الدم بالأكسجين أو مسنوى الغاز ات بات بالدم أو مدة العلاج

كذلك لوحظ ارتفاع مستوى بروتين S100B بالدم فى مرضى درضى التسمم الحاد بعقار الترامادول مقارنة

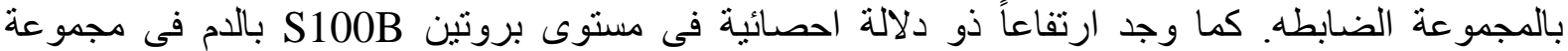

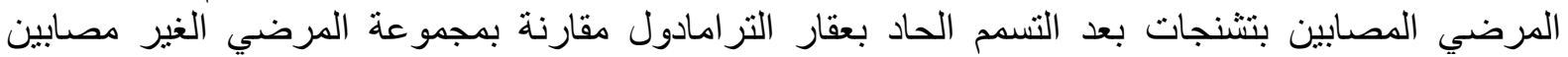
بتشنجات. وقد أظهرت النتائج أنه عند ارتفاع مستوى بروتين S100B بالدم أكثر من

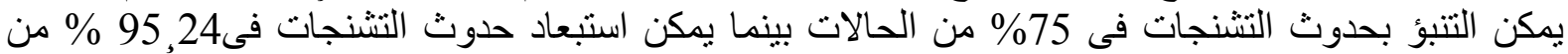

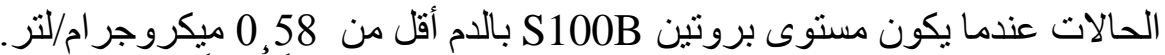

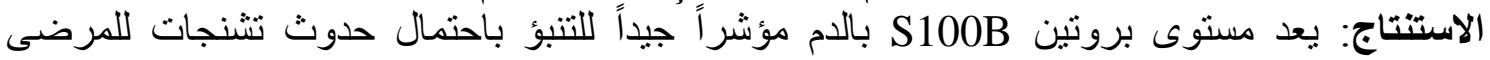

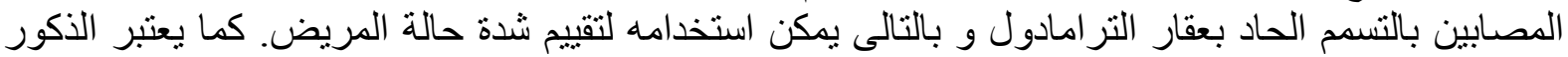

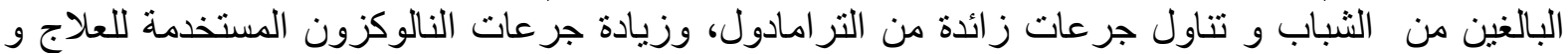

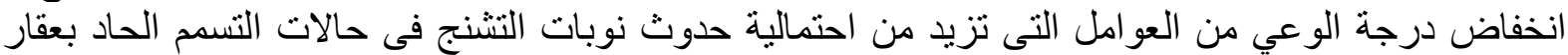

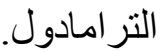
الكلمات المفتاحية: تر امادول ـ تشنجات ـ تسمم - بروتين S100B - مؤشر حيوى- عامل التنبؤ 